See discussions, stats, and author profiles for this publication at: https://www.researchgate.net/publication/272512911

\title{
Cyclic adenosine monophosphate protects renal cell lines against amphotericin B toxicity in a PKA-independent manner
}

Article in Drug and Chemical Toxicology · February 2015

DOI: 10.3109/01480545.2015.1012210 · Source: PubMed

\section{CITATIONS}

2

9 authors, including:

Flavia Dayrell França

Centro Universitário Norte do Espírito Santo/UFES

9 PUBLICATIONS 12 CITATIONS

SEE PROFILE

Kathleen Moraes

Southcoast Health System

3 PUBLICATIONS 10 CITATIONS

SEE PROFILE

Some of the authors of this publication are also working on these related projects:

Characterization of human Phospholipase $\mathrm{C}$ delta 4 View project

Project Oxidative stress View project
83

Joamyr Victor Rossoni Júnior

Universidade Federal de Ouro Preto

19 PUBLICATIONS 108 CITATIONS

SEE PROFILE

Dawidson A Gomes

Federal University of Minas Gerais

125 PUBLICATIONS 2,009 CITATIONS

SEE PROFILE 
This article was downloaded by: [J oamyr Rossoni Junior]

On: 07 August 2015, At: 17:23

Publisher: Taylor \& Francis

Informa Ltd Registered in England and Wales Registered Number: 1072954 Registered office: 5 Howick Place, London, SW1P IWG

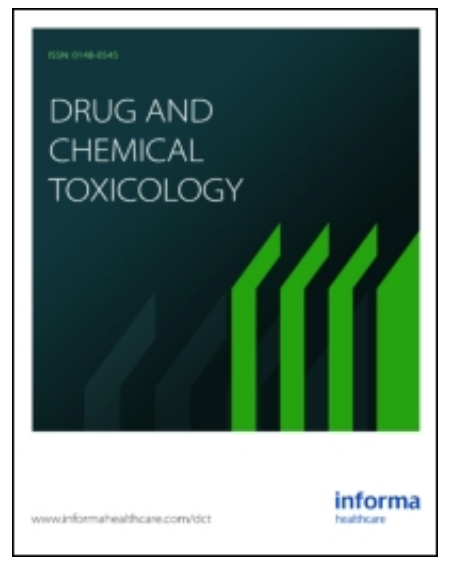

CrossMark

Click for updates

\section{Drug and Chemical Toxicology}

Publication details, including instructions for authors and subscription information: http:// www. tandfonline.com/loi/idct20

\section{Cyclic adenosine monophosphate protects renal cell lines against amphotericin B toxicity in a PKA- independent manner}

A. F. Ferreira ${ }^{a}$, F. D. França ${ }^{a}$, J. V. Rossoni J $r^{b}$, P. H. L. Viana ${ }^{a}$, K. C. M. Moraes ${ }^{c}$, D. A Gomes $^{a}$, D. C. Costa ${ }^{b}$, C. A. Tagliati ${ }^{d} \&$ M. M. Chaves ${ }^{a}$

${ }^{a}$ Departamento de Bioquímica e Imunologia, Instituto de Ciências Biológicas, Universidade Federal de Minas Gerais, Belo Horizonte, MG, Brazil,

${ }^{\mathrm{b}}$ Departamento de Ciências Biológicas, Instituto de Ciências Exatas e Biológicas, Universidade Federal de Ouro Preto, Mouro Preto, MG, Brazil,

"Departamento de Biologia, Universidade Estadual Paulista "J úlio de Mesquita Filho", Instituto de Biociências, Rio Claro, SP, Brazil, and

d Departamento de Análises Clinicas e Toxicológicas, Faculdade de Farmácia, Universidade Federal de Minas Gerais, Bioquímica, Belo Horizonte, Brazil

Published online: 15 J ul 2015.

To cite this article: A. F. Ferreira, F. D. França, J. V. Rossoni J r, P. H. L. Viana, K. C. M. Moraes, D. A. Gomes, D. C. Costa, C. A. Tagliati \& M. M. Chaves (2015): Cyclic adenosine monophosphate protects renal cell lines against amphotericin B toxicity in a PKA-independent manner, Drug and Chemical Toxicology

To link to this article: http:// dx. doi.org/ 10.3109/01480545.2015.1012210

\section{PLEASE SCROLL DOWN FOR ARTICLE}

Taylor \& Francis makes every effort to ensure the accuracy of all the information (the "Content") contained in the publications on our platform. However, Taylor \& Francis, our agents, and our licensors make no representations or warranties whatsoever as to the accuracy, completeness, or suitability for any purpose of the Content. Any opinions and views expressed in this publication are the opinions and views of the authors, and are not the views of or endorsed by Taylor \& Francis. The accuracy of the Content should not be relied upon and should be independently verified with primary sources of information. Taylor and Francis shall not be liable for any losses, actions, claims, proceedings, demands, costs, expenses, damages, and other liabilities whatsoever or howsoever caused arising directly or indirectly in connection with, in relation to or arising out of the use of the Content.

This article may be used for research, teaching, and private study purposes. Any substantial or systematic reproduction, redistribution, reselling, loan, sub-licensing, systematic supply, or distribution in any form to anyone is expressly forbidden. Terms \& Conditions of access and use can be found at http:// www.tandfonline.com/page/terms-and-conditions 


\title{
Cyclic adenosine monophosphate protects renal cell lines against amphotericin B toxicity in a PKA-independent manner
}

\author{
A. F. Ferreira' ${ }^{1}$, F. D. França ${ }^{1}$, J. V. Rossoni $\mathrm{Jr}^{2}$, P. H. L. Viana ${ }^{1}$, K. C. M. Moraes ${ }^{3}$, D. A. Gomes ${ }^{1}$, D. C. Costa ${ }^{2}$, \\ C. A. Tagliati ${ }^{4}$, and M. M. Chaves ${ }^{1}$ \\ ${ }^{1}$ Departamento de Bioquímica e Imunologia, Instituto de Ciências Biológicas, Universidade Federal de Minas Gerais, Belo Horizonte, MG, Brazil, \\ ${ }^{2}$ Departamento de Ciências Biológicas, Instituto de Ciências Exatas e Biológicas, Universidade Federal de Ouro Preto, Mouro Preto, MG, Brazil, \\ ${ }^{3}$ Departamento de Biologia, Universidade Estadual Paulista "Júlio de Mesquita Filho", Instituto de Biociências, Rio Claro, SP, Brazil, and \\ ${ }^{4}$ Departamento de Análises Clinicas e Toxicológicas, Faculdade de Farmácia, Universidade Federal de Minas Gerais, Bioquímica, \\ Belo Horizonte, Brazil
}

\begin{abstract}
Amphotericin B is the "gold standard" agent in the management of serious systemic fungal infections. However, this drug can cause nephrotoxicity, which contributes up to $25 \%$ of all acute kidney injuries in critically ill patients. Cyclic adenosine monophosphate can protect kidney cells from death due to injury or drug exposure in some cases. Hence, the objective of this work was to evaluate if cAMP could prevent cell death that occurs in renal cell lines subjected to AmB treatment and, if so, to assess the involvement of PKA in the transduction of this signal. Two different renal cell lines (LLC-PK1 and MDCK) were used in this study. MTT and flow cytometry assays showed increased cell survival when cells were exposed to CAMP in a PKA-independent manner, which was confirmed by western blot. This finding suggests that cAMP (db-cAMP) may prevent cell death caused by exposure to $A m B$. This is the first time this effect has been identified when renal cells are exposed to AmB's nephrotoxic potential.
\end{abstract}

Keywords

CAMP, cell protection, nephrotoxicity

\section{History}

Received 11 March 2014

Revised 30 October 2014

Accepted 22 January 2015

Published online 18 February 2015

\section{Introduction}

Avoiding renal injury is important in routine medical treatment, given that many drugs can lead to tubular damage and result in acute kidney dysfunction. Nephrotoxicity due to drug exposure contributes up to $25 \%$ of all acute kidney injuries in critically ill patients (Alvarez-Lerma et al., 2012). Amphotericin B (AmB) is categorized as a drug with a nephrotoxic potential that is still used in therapeutics because of its effectiveness. AmB has been the "gold standard" agent in the management of serious systemic fungal infections since the 1960s (Moen et al., 2009). Its molecule consists of a natural antibiotic from the polyene group, isolated from a strain of the actinomycete Streptomyces nodosus on soil collected in the Orinoco River region in Venezuela (LaniadoLaborín et al., 2009).

The AmB pharmacological mechanism of action is based on the linkage of its hydrophobic moiety to the fungal cell membrane, producing an aggregate that forms transmembrane

Address for correspondence: Dra. Míriam Martins Chaves, Departamento de Bioquímica e Imunologia, Instituto de Ciências Biológicas, Universidade Federal de Minas Gerais - Caixa Postal 486, 30161-970, Belo Horizonte, Minas Gerais, Brazil. Tel: +55 313409 2660. Fax: +55 313409 2614. E-mail: chavesmm@icb.ufmg.br pores (Johnson \& Einstein, 2007). This leads to an increase in the permeability of membrane depolarization and proton and monovalent cations, which culminates in the disturbance of osmotic equilibrium and cell death (Sundar et al., 2014). It is possible to activate certain biochemical pathways in order to protect tissues from injuries. To effectively reduce AmB nephrotoxicity, it would be interesting to find agents that could act as protectors of cell viability.

Cyclic adenosine monophosphate (cAMP) is ubiquitous and regarded as an intracellular messenger responsible for multiple functions, including protection against cell death due to drug use in renal tissue (Qin et al., 2012). cAMP is produced by Adenylate cyclase activity which is, in turn, activated by a membrane receptor responsive to an intracellular or membrane stimulus (Dodge-Kafka et al., 2005). The signal from cAMP can be carried through ion channels, exchange protein directly activated by cAMP (Epac), and protein kinase A (PKA) (Breckler et al., 2011). PKA is a ubiquitous protein kinase expressed throughout the renal tissue, which has a wide range of functions, including cell protection (Li et al., 2014).

Thus, the objective of this work was to evaluate if cAMP could protect renal cell lines from death due to AmB exposure and, if so, to assess the involvement of PKA in the transduction of this signal. 


\section{Materials and methods}

\section{Drugs}

AmB at a purity of $90 \%$ was donated by Cristália (Produtos Químicos Farmacêuticos Ltda, Itapira, SP, Brazil). A stock solution of $300 \mu \mathrm{g} / \mathrm{mL} \mathrm{AmB}$ in sterile buffer solution (PBS) was prepared and stored at $-20^{\circ} \mathrm{C}$. Later, this stock solution was applied in each plate well seeded with both cells lines resulting in final concentrations of $30 \mu \mathrm{g} / \mathrm{mL}$ or $4 \mu \mathrm{g} / \mathrm{mL}$ of AmB depending on the assay. The PKA Pathway Inhibitor (H89 - Calbiochem Merck KGaA, Darmstadt, Germany) was dissolved in anhydrous dimethylsulfoxide (DMSO) to form a stock solution that was 1000 times the required final concentration. The inhibitor stock solution was aliquoted and stored at $-20^{\circ} \mathrm{C}$. The stock solution was diluted immediately prior to use and cells were pretreated with $1.0 \mu \mathrm{M}$ of $\mathrm{H} 89$ for $30 \mathrm{~min}$. Cellular viability when cells were exposed to H89 was 93\% (Chaves et al., 2009). The concentration of db-cAMP (N6, 2'-O-dibutiriladenosina 3': 5'-cyclic monophosphate-db-cAMP - Sigma, St. Louis, MO) use solution was $10^{-5} \mathrm{M}$ (Chaves et al., 2008).

\section{Cell culture}

Considering the complexity of the kidney, we used in this study two different cell lines from different portions of the renal tissue as a way of improving our experimental model. Cell lines LLC-PK1 (porcine kidney proximal tubular cells passages 10-20) and MDCK cells (canine distal tubular cells - passages 5-15) were obtained from the Cell Bank at Universidade Federal do Rio de Janeiro (UFRJ). They were cultivated in an RPMI-1640 culture medium (Sigma St. Louis, MO) and supplemented with $10 \%(\mathrm{v} / \mathrm{v})$ bovine fetal serum (Invitrogen Co Ltd, Carlsbad, CA), $100 \mathrm{IU}$ penicillin $/ \mathrm{mL}$, and $100 \mu \mathrm{g}$ streptomycin $/ \mathrm{mL}$ (Sigma, St. Louis, MO). We used RPMI-1640 culture medium because it contains all the substances necessary to maintain cell integrity and proliferation. Cells were cultivated in $75 \mathrm{~cm}^{2}$ flasks (TPP, Sigma Aldrich, St. Louis, MO) and kept at $37^{\circ} \mathrm{C}$ with $5 \% \mathrm{CO}_{2}$.

\section{MTT assay}

MTT [3-(4,5-dimethylthiazol-2-yl)-2,5-diphenyltetrazolium bromide] assay was performed based on the protocol proposed by Mosman (1983). To study the involvement of cAMP in protection against AmB (Cristália Produtos Químicos Farmacêuticos Ltda, Itapira, SP, Brazil) induced cell death, LLC-PK1, and MDCK cells were treated with $10^{-5} \mathrm{M}$ db-cAMP (commercial analogue of cAMP - Sigma Aldrich, St. Louis, MO), followed by AmB $(30.0 \mu \mathrm{g} / \mathrm{mL})$ treatment. The concentration of $30.0 \mu \mathrm{g} / \mathrm{mL}$ of $\mathrm{AmB}$ represents the IC 50 value for both cells lines as assessed by dosedependent curve (data not shown). Cells were seeded $\left(5.0 \times 10^{3}\right.$ cells/well) on 96-well plates (TPP, Sigma Aldrich, St. Louis, MO) and incubated with $\mathrm{AmB}$ and/or db-cAMP (Sigma Aldrich, St. Louis, MO) for $24 \mathrm{~h}$ at $37^{\circ} \mathrm{C}$, $5 \% \mathrm{CO}_{2}$. Having completed the exposure time, the medium containing the drug was removed, $20 \mu \mathrm{L}$ of MTT (Sigma Aldrich, St. Louis, MO) solution $(5.0 \mathrm{mg} / \mathrm{mL})$ was added, and plates were incubated for one hour at $37{ }^{\circ} \mathrm{C}, 5 \% \mathrm{CO}_{2}$.
The MTT solution was then removed, and $100 \mu \mathrm{L}$ of DMSO (Sigma Aldrich, St. Louis, MO) was added to each well. The absorbance was read at $570 \mathrm{~nm}$ (Thermo Plate model TP-READER, Molecular Devices, Oceanside, CA) and the results were expressed as a percentage of the viability present in treated cells compared with negative control cells. Tests were performed in sextuplicates from three independent experiments.

\section{Flow cytometry assays}

A flow cytometry DNA fragmentation assay was employed as a quantitative measure of cell death (Ricardi \& Nicoletti, 2006). To study the involvement of cAMP in protection against AmB induced cell death, LLC-PK1 and MDCK cells were seeded in 24 well plates (TPP, Sigma Aldrich, St. Louis, MO) and treated with $10^{-5} \mathrm{M}$ db-cAMP (commercial analogue of cAMP) followed by AmB $(4.0 \mu \mathrm{g} / \mathrm{mL})$ treatment. To study the involvement of PKA signaling pathway in cell protection against $\mathrm{AmB}$, cells were pretreated for $30 \mathrm{~min}$ with $1.0 \mu \mathrm{M} \mathrm{H} 89$ (PKA activation inhibitor), followed by AmB $(4.0 \mu \mathrm{g} / \mathrm{mL})$ and $10^{-5} \mathrm{M}$ db-cAMP treatment. Twenty-four hours after treatment, the supernatant of each well was collected and centrifuged. The resulting pellet was combined to cells that were lysed and collected from each corresponding well by the exposure to $300 \mu \mathrm{L}$ of a hypotonic solution containing $0.5 \%$ Triton X-100 and $50 \mu \mathrm{g} / \mathrm{mL}$ propidium iodide (propidium iodide, Invitrogen, Carlsbad, CA). Cell lyses was optimized by homogenization by pippeting the material up and down. Cells were incubated at $4{ }^{\circ} \mathrm{C}$ for $1 \mathrm{~h}$ and analyzed in a flow cytometer (Guava easyCyte BHT - Millipore, Billerica, MA) for shifts in propidium iodide fluorescence that were indicative of nuclei with hypodiploid DNA content. Assays were performed in triplicates from three independent experiments.

\section{Western blot assay}

MDCK and LLC-PK1 cells were grown on $75 \mathrm{~cm}^{2}$ flasks until $90 \%$ confluence was reached. Next, cells were exposed to different substances in accordance with the following groups: negative control (untreated cells); positive control $10 \mu \mathrm{M}$ forskolin (Burgos et al., 2004) (Sigma-Aldrich, St. Louis, MO, Sigma ${ }^{\circledR}$ ); cells treated with db-cAMP $10^{-5} \mathrm{M}$; cells treated with $\mathrm{AmB}(4.0 \mu \mathrm{g} / \mathrm{mL})$; cells treated with $\mathrm{H} 89(1.0 \mu \mathrm{M})$; cells treated with $\mathrm{AmB}(4.0 \mu \mathrm{g} / \mathrm{mL})$ associated with db-cAMP $(20 \mu \mathrm{M})$; cells pre-treated with $\mathrm{H} 89(1.0 \mu \mathrm{M})$ for $30 \mathrm{~min}$ following $\mathrm{AmB}(4.0 \mu \mathrm{g} / \mathrm{mL})$ associated with db-cAMP $\left(10^{-5} \mathrm{M}\right)$ After chemical additions, cells were incubated for three hours at $37^{\circ} \mathrm{C}, 5 \% \mathrm{CO}_{2}$. Next, cells were collected using trypsin. After centrifugation of samples, the supernatant was discarded and the precipitate was resuspended in $500 \mu \mathrm{L}$ of lysis buffer (the lysis buffer is a solution composed by Tris $\mathrm{HCl} 1.0 \mathrm{mM}$; EDTA $0.5 \mathrm{M}$; $\mathrm{NaCl}$ $5.0 \mathrm{M}$; DTT; Nonidet P40; protease inhibitor cocktail Sigma-Aldrich, St. Louis, MO - Sigma ${ }^{\circledR}$ ). The homogenate was incubated on ice for $10 \mathrm{~min}$, and next the samples were centrifuged for $2 \mathrm{~h}$ at $4380 \mathrm{~g}$ at $4{ }^{\circ} \mathrm{C}$. The supernatant was collected and transferred to a new tube, and proteins were finally quantified using Bradford (1976) assay in a 
spectrophotometer (spectrophotometer cuvette digital Biosystems, Waltham, MA) at $595 \mathrm{~nm}$ (Burgos et al., 2004). The sample buffer used to prepare the samples for loading the gel was $5 \times$ Loading Buffer (Fementas - Thermo Fisher Scientific Inc., Waltham, MA). After preparing the samples, they were incubated for $5 \mathrm{~min}$ in $95^{\circ} \mathrm{C}$. Next, proteins were loaded in a $10 \%$ polyacrilamyde gel. After the electrophoresis, the proteins were electrotransfered onto a nitrocellulose membrane adapting the methodology previously described (Sambrook et al., 1989) and then incubated with the primary antibody (rabbit anti-PRKACG antibody polyclonal (SigmaAldrich, St. Louis, MO), with a dilution factor of 1:250 for $12 \mathrm{~h}$ at $4{ }^{\circ} \mathrm{C}$. To effectively assess that our target in western blot assay was in fact the active form of PKA, we used this specific antibody that links exclusively to the phosphorilated form of this protein. After incubation, the membranes were extensively washed with TBST buffer $(500 \mathrm{mmol} / \mathrm{L} \mathrm{NaCl}$, $20 \mathrm{mmol} / \mathrm{L}$ Tris-HCL, and 0.4\% Tween 20; pH 7.4), followed by the secondary antibody incubation (anti-rabbit IgG-peroxidase, antibody produced in goat, Sigma-Aldrich, St. Louis, MO) for $2 \mathrm{~h}$ at $4{ }^{\circ} \mathrm{C}$. The secondary antibody was diluted by a factor of 1:10000, and the same extensive washes with TBST were performed. Finally the bands were visualized after incubation with Luminol Enhancer Solution (GE Healthcare, Menlo Park, CA) for $1 \mathrm{~min}$, followed by a 15-s exposure to Hyperfilm-ECL (GE Healthcare, Menlo Park, CA). The results were quantified using Quantity One, Bio-Rad, Hercules, CA.

\section{Statistical analysis}

All results were analyzed by the ANOVA and the Tukey post-test. The results obtained in Western Blot assays were first analyzed by image analysis software Quantity One, Bio-Rad, Hercules, CA.

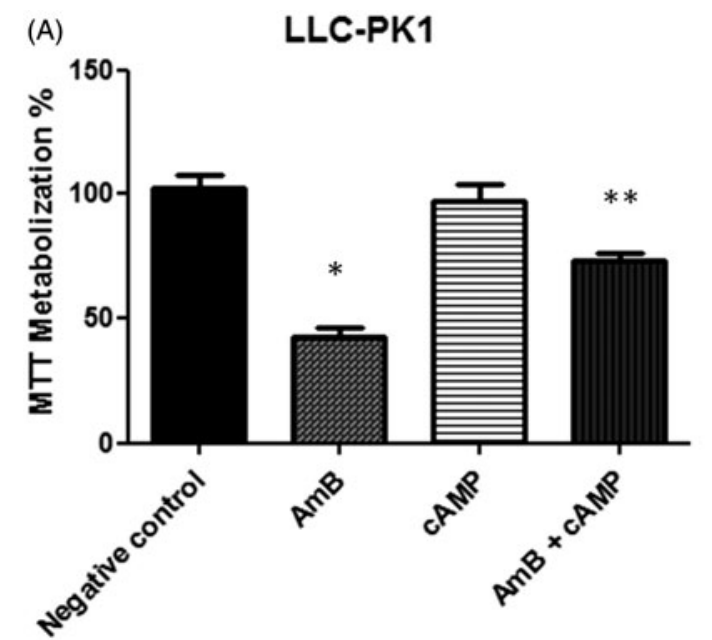

\section{Results}

Influence of CAMP in cellular viability after treatment with amphotericin B

Both cell lines showed a similar response to AmB, with lower MTT metabolization compared with negative control groups which suggests a decrease in cell viability $(p<0.05)$ (Figure 1 - panels A and B). Groups exposed to db-cAMP from both cell lines had no changes in MTT metabolization in comparison to negative controls. There is a significant increase $(p<0.05)$ in MTT metabolization in the groups submitted to the association of drug and db-cAMP compared with the AmB group in both LLC-PK1 and MDCK cells. This suggests that cell viability increases when cells are exposed to this drug associated to db-cAMP compared with the groups exposed only to AmB. There was no significant difference between cell lines despite the fact that they represent different areas of the renal tissue. Further studies must be done to explain this aspect of the results.

\section{CAMP influence in renal cells lines integrity when submitted to amphotericin B}

LLC-PK1 and MDCK cells showed an increased rate of DNA fragmentation when submitted to AmB compared with the negative control groups (Figure 2 - panels A and B). Groups submitted to the association of drug and db-cAMP showed a decrease DNA fragmentation, which suggests a decline in cell death events compared with the groups exposed to AmB only $(p<0.05)$. In order to verify the hypothesis that the observed protective effect would be carried by PKA, we carried out another flow cytometry experiment in which cells were previously exposed to H89, a potent inhibitor of PKA activation (Reber et al., 2012), and then submitted to treatment with the association of drug and db-cAMP. Results showed a significant decrease in DNA

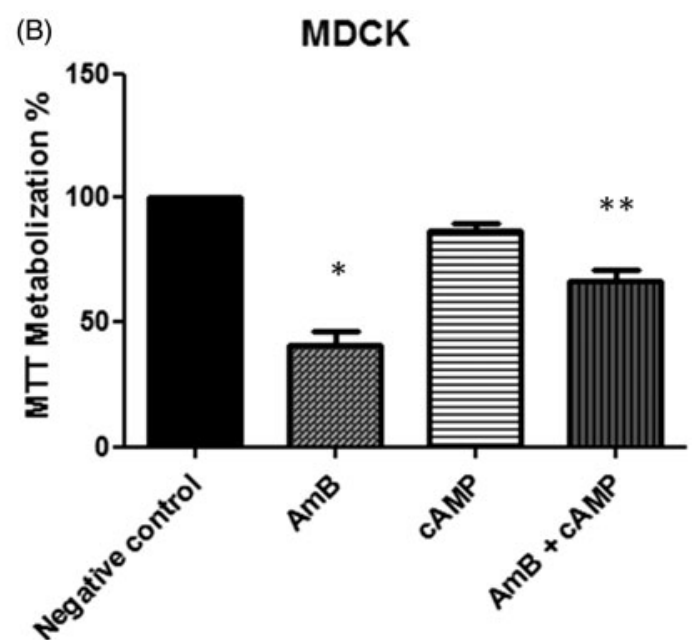

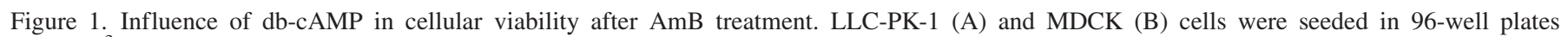

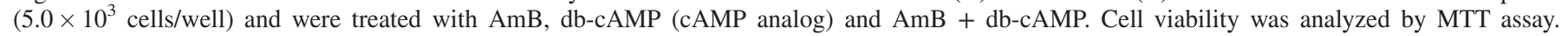

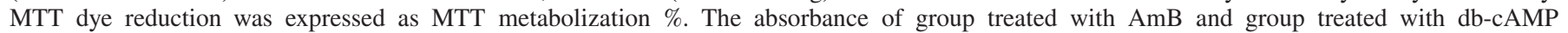

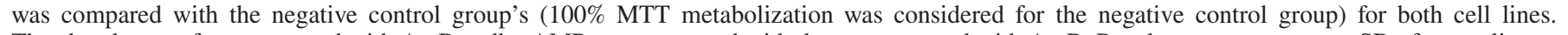

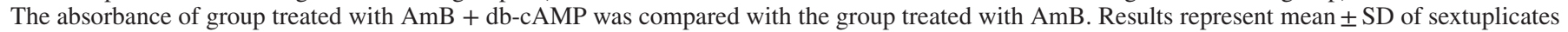

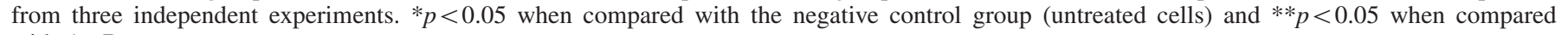
with AmB. 

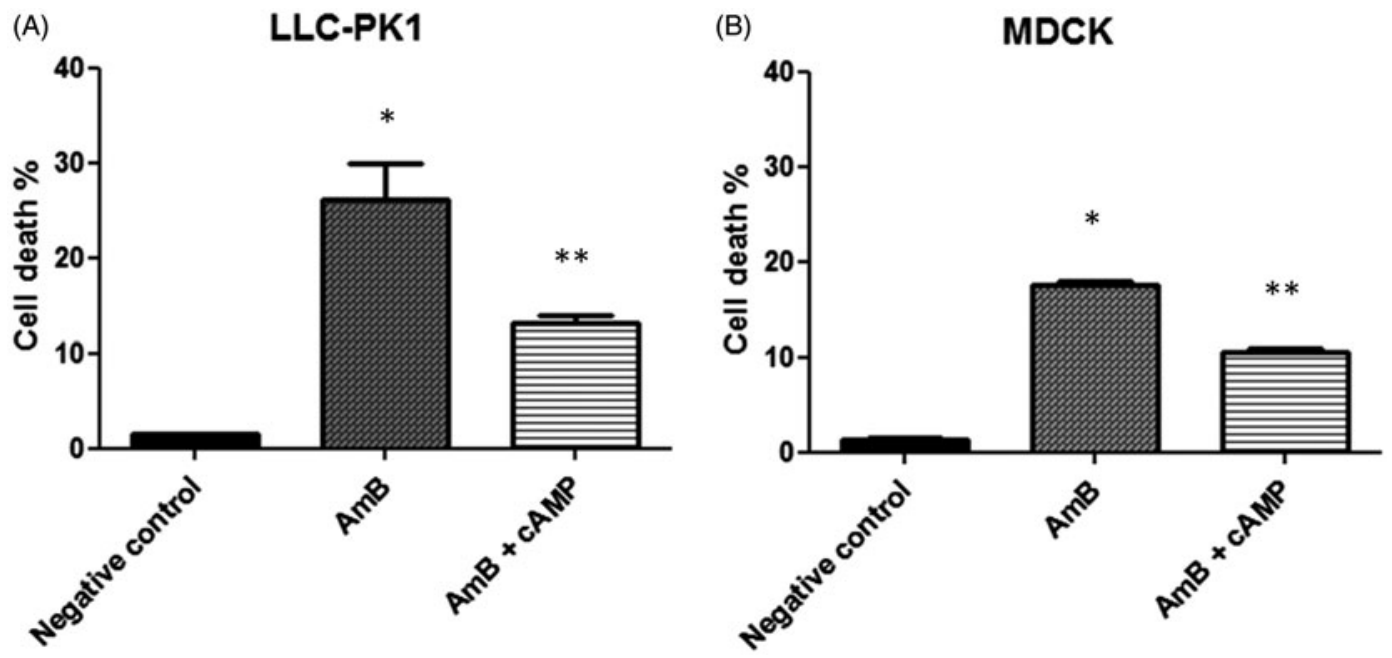

Figure 2. cAMP (db-cAMP) influence in LLC-PK1 (A) and MDCK (B) cells integrity when submitted to AmB. Cells from both cell lines were seeded in 24-well plates $\left(1.0 \times 10^{4}\right.$ cells/well $)$ and were treated with $\mathrm{AmB}(4.0 \mu \mathrm{g} / \mathrm{mL})$ and AmB + cAMP in triplicates. Cell state of integrity was evaluated as cell death percentage and was analyzed after staining with PI. A flow cytometry assay was employed as a quantitative measure of DNA fragmentation which suggests cell death. Results are expressed as percentage of events from a total of 5000 events. Results represent mean \pm SD of triplicates $(n=3)$ from three independent experiments. ${ }^{*}$ and $* *$ mean significantly different from negative control or group treated with AmB $(p<0.05)$.
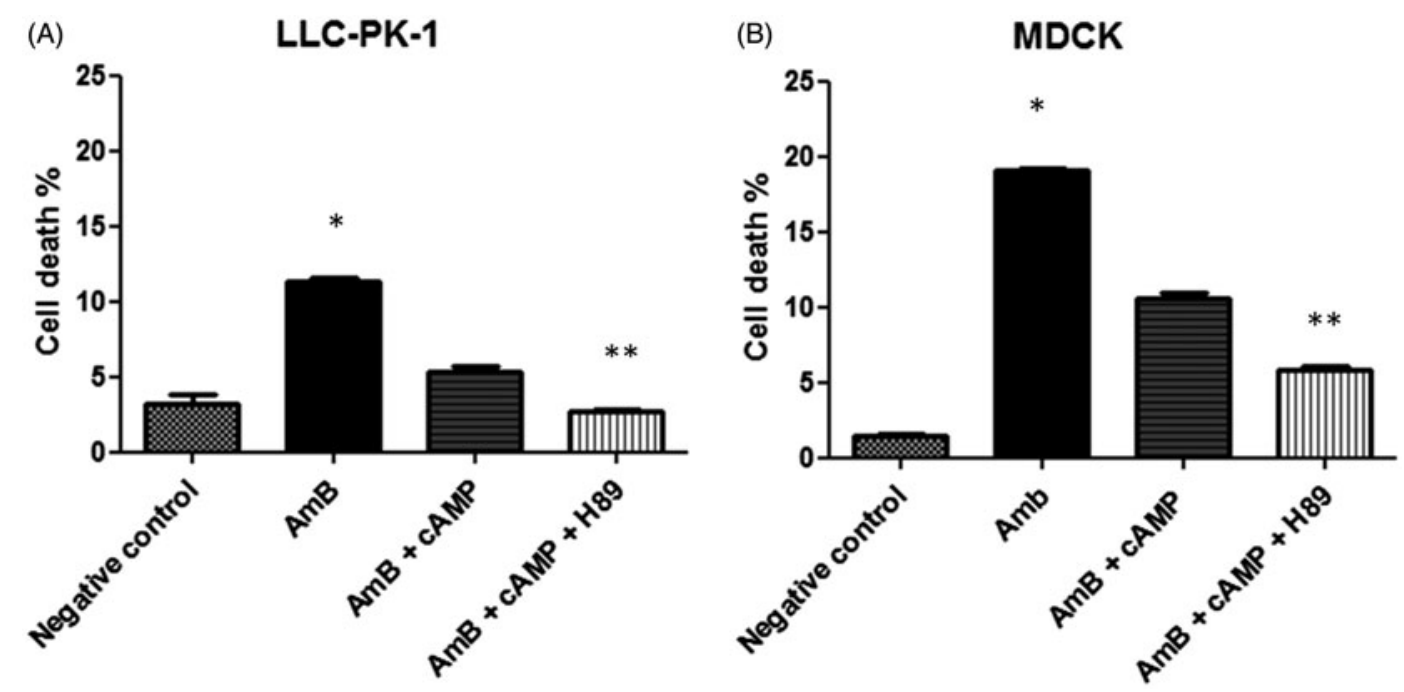

Figure 3. H89 influence in LLC-PK1 (A) and MDCK (B) cells integrity when submitted to AmB associated with cAMP - flow cytometry assay. Cell integrity was expressed as percentage of cell death. Cells were seeded in a 24 -well plate $\left(1.0 \times 10^{4}\right.$ cells/well $)$ and were treated with AmB, $\mathrm{AmB}+\mathrm{cAMP}$ (db-cAMP, a cAMP analog) and AmB + cAMP + H89 (PKA inhibitor) in triplicates. DNA fragmentation was analyzed after staining with PI. The flow cytometry assay was employed as a quantitative measure of DNA fragmentation which suggests cell death. Results are expressed as percentage of events from a total of 5000 events. Results represent mean \pm SD of triplicates $(n=3)$ from three independent experiments. * and **mean significantly different from negative control or group treated with AmB + cAMP $(p<0.05)$.

fragmentation when cells from both lines are subjected to the combination of AmB and db-cAMP subsequent to treatment with the inhibitor H89 compared with the group exposed only to the association (AmB and db-cAMP), and this suggests a decrease in cell death events (Figure 3). This suggests that the protective effect of cAMP is independent from PKA activation in both MDCK and LLCPK-1. Similar to the results from the MTT assay, there was no difference between the responses from the cell lines despite the fact that they represent different areas of the renal tissue. Further studies must be conducted to explain why this is so.

\section{Western blot assay}

Results in Figure 4 showed the involvement of the cAMP signaling pathway in the nephrotoxicity of AmB. Positive control (Forskolin), cAMP, and the association between AmB and db-cAMP induced a significant activation of PKA in LLC-PK1 and MDCK cell lines (Figure 4 - panels A and B). Cells exposed to AmB did not show significant increase in PKA activation compared with negative control in both cell lines. When cells were pretreated with H89 and then exposed to the association of AmB and db-cAMP, a significant 
(A)

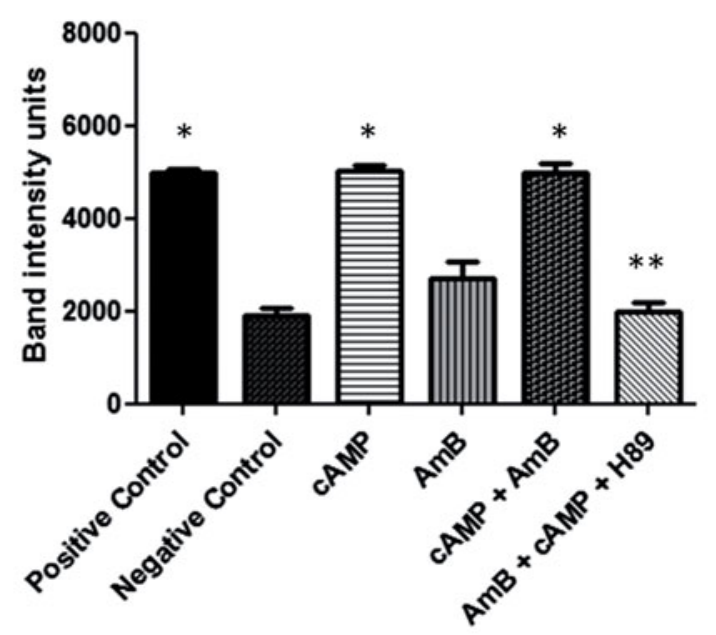

LLC-PK1
(B)

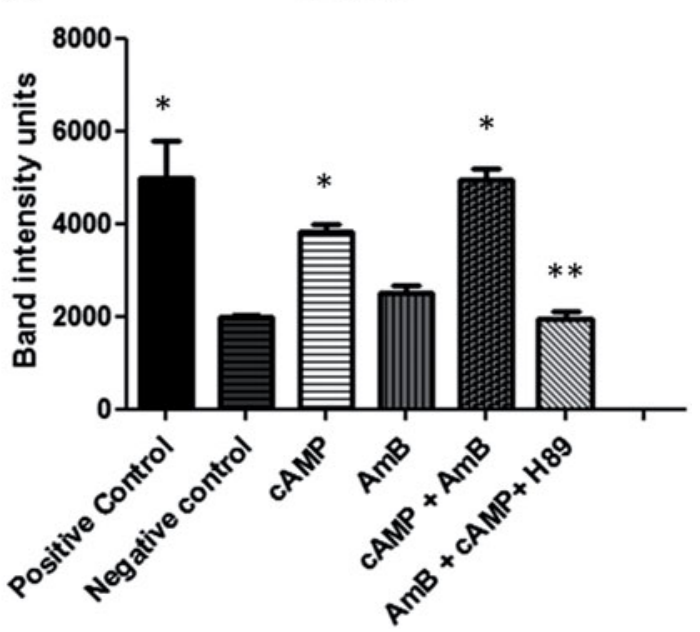

aPKA - 49KDa

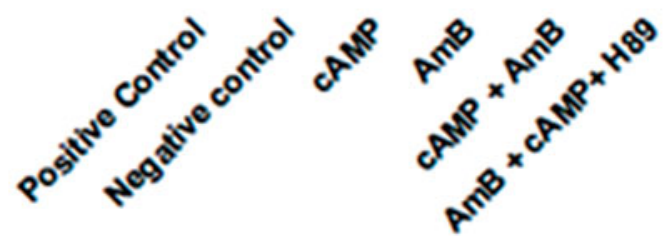

MDCK

aPKA - 49KDa

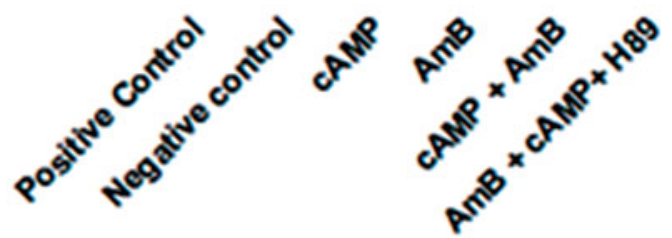

Figure 4. H89 influence in PKA activation in LLC-PK1 and MDCK cells when submitted to amphotericin B associated with cAMP - Western blot assay. Positive control: Forskolin $(10 \mu \mathrm{M})$; negative control: untreated cells; cAMP (db-cAMP); AmB $(4.0 \mu \mathrm{g} / \mathrm{mL})$. ${ }^{*} p<0.05$ for values significantly different from the negative control groups. ${ }^{*} p<0.05$ for values different from those of the groups exposed to the association between AmB and db-cAMP. Image analysis was done by software Quantity One, Bio-Rad, Hercules, CA, and later statistical analysis was performed by the ANOVA and the Tukey post-test. The analyses were performed in triplicate $(n=3)$.

decrease in band intensity could be observed when compared with the group treated with $\mathrm{AmB}$ and db-cAMP (Figure 4 - panels A and B).

\section{Discussion}

The present study demonstrates that db-cAMP may protect renal cell lines against AmB toxicity in a PKA-independent manner. This was shown when two different cell lines, one of proximal tubular epithelial origin (LLC-PK-1) and the other composed of collecting duct cells (MDCK) were exposed to db-cAMP in association with AmB treatment. An increase in cell survival could be observed when comparing groups exposed to the association between drug and db-cAMP and the groups exposed to AmB only as shown by MTT and flow cytometry assays. Flow cytometry assay results also showed that this cytoprotective effect occurred independently from PKA activation, in both cell lines, as H89 exposure, prior to the association between drug and db-cAMP incubation, did not alter the protective effect. Western Blot assays, performed in both cell lines, confirmed that there was no activation of PKA in groups exposed to H89. Db-cAMP has the capacity to trigger other proteins that are inducible by cAMP besides PKA (Spina et al., 2012).

Nowadays, many drugs used in therapeutics demonstrate severe nephrotoxic potential and drug-induced acute kidney injury (AKI) have been implicated in $8-60 \%$ of all cases of in-hospital AKI. As such, AKI is recognized as a source of 
significant morbidity and mortality (Khalili et al., 2013). This makes designing strategies that can effectively reduce such effects imperative (Mishima et al., 2006).

A study conducted by Stokman showed that renal epithelial cells subjected to ischemia, followed by reperfusion (which commonly contributes to renal failure), leading to a loss of integrity of cell-cell junctions, were capable of maintaining their integrity when submitted to incubation with another molecule, 8-PCPT-2'-O-Me-cAMP, in a PKA-independent manner, since that particular cAMP analog lacks PKA activation capacity (Stokman et al., 2011).

The intrarenal administration of 8-PCPT-2'-O-Me-cAMP in vivo led to the same effect when mice underwent renal injury caused by ischemia followed by reperfusion. This study demonstrated the importance of cell-cell interactions preservation, and cAMP cell adhesion-dependent signaling pathways to resist against renal damage in a new way, involving the Rap protein family.

Other studies have also proven that cAMP plays a key protective role against kidney injury as an adverse effect of cisplatin use (Arany et al., 2008; Li et al., 2010; Mishima et al., 2006). Also, there is evidence that the use of 8-PCPT-2'-O-Me-cAMP in mice kidney proximal tubule cells leads to the preservation of the integrity of those cells when exposed to cisplatin, a highly nephrotoxic drug, by preventing cell detachment and apoptosis (Qin et al., 2012). These findings are in agreement with the present study, as MDCK and LLC-PK-1 cells resisted cell death due to exposure to AmB when submitted to the association between $\mathrm{db}-\mathrm{cAMP}$ and AmB.

$\mathrm{AmB}$ is still considered the first-line treatment for cryptococcosis and histoplasmosis (Johnson et al., 2002; Moen et al., 2009; Saag et al., 2000). There are also reports of its use in resistance to azoles, whether alone or in combination (Chandrasekar, 2011), even with its high nephrotoxicity. It has been proposed that AmB toxicity is due to its capacity to provoke a loss of osmolarity in proximal tubular cells, afferent arteriolar vasoconstriction followed by reperfusion, and an elevated pro-inflammatory cytokine response, which all result in cell death (Louis et al., 2013). The present study suggests that db-cAMP may prevent cell death in LLC-PK-1 and MDCK cell lines due to AmB exposure. Further studies are necessary to assess the precise mechanism involved in this process. It should be investigated if the effect initiated by cAMP is carried out by ion channels or if other proteins are responsible for it, as Epac, for example. When cAMP activates Epac, it functions as an exchange factor for the small GTPase Rap1, mediating replacement of GDP for GTP, consequently leading to activation of Rap1. Among the processes known to be influenced by Rap1 are integrin-mediated adhesion to the extracellular matrix and the preservation of cell-cell contacts (Hogan et al., 2004). Cyclic adenosime monophosphate also regulates electrogenic absorption of $\mathrm{Na}+$ by the amiloridesensitive epithelial $\mathrm{Na}+$ channel, which is essential for the maintenance of sodium equilibrium in renal tissue (Honegger et al., 2006). It is important to know if the protective effect is a result of ion channels or Epac activation. If Epac is involved, then it would be important to assess if it is the ability of this protein in maintaining cell-cell interactions and cell adhesion the reason why there is protection of renal cells against amphotericin B nephrotoxicity.

\section{Conclusion}

It can be concluded that cAMP (db-cAMP) could protect renal cells from death due to AmB exposure. This is the first time that this effect is shown when renal cells are exposed to the nephrotoxic potential of AmB.

\section{Acknowledgements}

The authors thank Gláucia A. A. Carvalho for excellent technical assistance.

\section{Declaration of interest}

The authors report that they have no conflicts of interest. UFMG (Universidade Federal de Minas Gerais), UFOP (Universidade Federal de Ouro Preto), FAPEMIG (Fundação de Amparo e Pesquisa de Minas Gerais Log Number: APQ-00596-08), CAPES (Coordenação de Aperfeiçoamento de Pessoal de Nível Superior), and CNPQ (Conselho Nacional de Pesquisa) supported this paper.

\section{References}

Alvarez-Lerma F, Soriano MC, Rodriguéz M, et al. (2012). Impact of liposomal amphotericin B on renal function in critically ill patients with renal function impairment. Rev Esp Quimioter 25:206-215.

Arany I, Herbert J, Herbert Z, Safirstein RL. (2008). Restoration of CREB function ameliorates cisplatin cytotoxicity in renal tubular cells. Am J Physiol Renal Physiol 294:F577-F581.

Bradford MM. (1976). A rapid and sensitive method for the quantitation of microgram quantities of protein utilizing the principle of proteindye binding. Anal Biochem 72:248-254.

Breckler M, Berthouze M, Laurent AC, et al. (2011). Rap-linked cAMP signaling Epac proteins: compartmentation, functioning and disease implications. Cell Signal 23:1257-1266.

Burgos PV, Klattenhoff C, Fuente E, et al. (2004). Cholesterol depletion induces PKA-mediated basolateral-to-apical transcytosis of the scavenger receptor class B type I in MDCK cells. PNAS 101:3845-3850.

Chandrasekar P. (2011). Management of invasive fungal infections: a role for polyenes. J Antimicrob Chemother 66:457-465.

Chaves MM, Costa DC, Oliveira BF, et al. (2009). Role PKA and p38 MAPK on ROS production in neutrophil age-related: lack of IL-10 effect in older subjects. Mech Ageing Dev 130:588-591.

Chaves MM, Costa DC, Souza DAC, et al. (2008). Correlation between ROS production and InsP3 released by granulocytes from type 1 diabetic patients in a cAMP-dependent manner. Curr Aging Sci 1:51-55.

Dodge-Kafka KL, Soughayer J, Pare GC, et al. (2005). The protein kinase A anchoring protein $\mathrm{mAKAP}$ coordinates two integrated cAMP effector pathways. Nature 437:574-578.

Hogan C, Serpente N, Cogram P, et al. (2004). Rap1 regulates the formation of E-cadherin-based cell-cell contacts. Mol Cell Biol 24: $6690-6700$

Honegger KJ, Capuano P, Winter C, et al. (2006). Regulation of sodiumproton exchanger isoform 3 (NHE3) by PKA and exchange protein directly activated by cAMP (EPAC). Proc Natl Acad Sci USA 103: 803-808.

Johnson RH, Einstein HE. (2007). Amphotericin B and coccidioidomicosis. Ann NY Acad Sci 1111:434-441.

Johnson PC, Wheat LJ, Cloud GA, et al. (2002). Safety and efficacy of liposomal amphotericin B compared with conventional amphotericin $\mathrm{B}$ for induction therapy of histoplasmosis in patients with AIDS. Ann Intern Med 137:105-109.

Khalili H, Bairami S, Kargar M. (2013). Antibiotics induced acute kidney injury: incidence, risk factors, onset time and outcome. Acta Med Iran 51:871-878.

Laniado-Laborín R, Cabrales-Vargas MN. (2009). Amphotericin B: side effects and toxicity. Rev Iberoam Micol 26:223-227. 
Li M, Balamuthusamy S, Khan AM, et al. (2010). Pituitary adenylate cyclase-activating polypeptide ameliorates cisplatin-induced acute kidney injury. Peptides 31:592-602.

Li X, Tao H, Xie K, et al. (2014). cAMP signaling prevents podocyte apoptosis via activation of protein kinase $\mathrm{A}$ and mitochondrial fusion. PLoS One 9:e92003. doi:10.1371/journal.pone.0092003.

Louis YAC, Mihai GN, Bee CT, et al. (2013). An elevated pro-inflammatory cytokine response is linked to development of amphotericin B-induced nephrotoxicity. J Antimicrob Chemother 68: $1655-1659$.

Mishima K, Baba A, Matsuo M, et al. (2006). Protective effect of cyclic AMP against cisplatin-induced nephrotoxicity. Free Radic Biol Med 40:1564-1577.

Moen MD, Lyseng-Williamson KA, Scott LJ. (2009). Liposomal amphotericin B: a review of its use as empirical therapy in febrile neutropenia and in the treatment of invasive fungal infections. Drugs 69:361-392.

Mosman T. (1983). Rapid colorimetric assay for cellular growth and survival: application to proliferation and cytotoxicity assays. J Immunol Meth 65:55-63.

Qin Y, Stokman G, Yan K, et al. (2012). cAMP signalling protects proximal tubular epithelial cells from cisplatin-induced apoptosis via activation of EPAc. Br J Pharmacol 165:1137-1150.
Reber LL, Daubeuf F, Nemska S, Frossard N. (2012). The AGC kinase inhibitor H89 attenuates airway inflamation in mouse models of asthma. PLoS One 7:e49512. doi:10.1371/journal.pone.0049512.

Ricardi C, Nicoletti I. (2006). Analysis of apoptosis by propidium iodite staining and flow citometry. Nat Protoc 1:1458-1461.

Saag MS, Graybill RJ, Larsen RA. (2000). Practice guidelines for the management of cryptococcal disease. Infectious Diseases Society of America. Clin Infect Dis 30:710-718.

Sambrook J, Fritschi EF, Maniatis T. (1989). Molecular cloning: a laboratory manual. New York: Cold Spring Harbor Laboratory Press.

Spina A, Di Maiolo F, Esposito A, et al. (2012). cAMP elevation down-regulates $\beta 3$ integrin and focal adhesion kinase and inhibits leptin-induced migration of MDA-MB-231 breast cancer cells. Biores Open Access 1:324-332.

Stokman G, Qin Y, Genieser HG, et al. (2011). Epac-rap signaling reduces cellular stress and ischemia-induced kidney failure. J Am Soc Nephrol 22:859-872.

Sundar S, Pandey K, Thakur CP, et al. (2014). Efficacy and safety of amphotericin B emulsion versus liposomal formulation in Indian patients with visceral leishmaniasis: a randomized, openlabel study. PLoS Negl Trop Dis 8:e3169. doi:10.1371/journal. pntd.0003169. 